\title{
The significance of the categories of Spinoza's ethics for cultural historical research La importancia de las categorías de la ética de Spinoza para la investigación histórico-cultura
}

\author{
Bernd Fichtner*
}

DOI: http://dx.doi.org/10.20435/938

\begin{abstract}
The starting-point for this presentation is a joint Brazilian-German research project on "Reading and Writing as a Cultural Praxis of Youth". This was an empirical qualitative study on the basis of open "dialogical interviews" (Bakhtin) which focused on this praxis of youths. In addition to Bakhtin as a methodological perspective, Lurija's concept of a "romantic science" became fundamental to our project ${ }^{1}$. The goals of our research were as follows: 1 . To understand reading and writing in their interrelationship as a specific form of cultural praxis; 2 . To contribute by means of research on this specific praxis to the theoretical dimensions of the concept of "cultural praxis" as a symbolically mediated praxis; 3 . To better understand - precisely by means of this praxis on the part of children and youths - current changes in reading and writing. To this end, we proceeded from the assumption that children and youths have a particular sensitivity for symbolizing their experiences with regard to new developments in a society ${ }^{2} ; 4$. We intended to concretize these goals in a "cultural comparison" of this praxis on the part of Brazilian and German youths. With the following remarks, we will not be presenting the project in its entirety, its results, or the discussion thereof. Rather, we would like to discuss one particular aspect in more detail: the problem of cultural differences, the explosive nature of which only became evident in the course of the research process.
\end{abstract}

\section{Key words}

Cultural praxis; cultural comparison; cultural differences.

\section{Resumen}

El punto de partida de esta presentación es un proyecto de investigación Brasil-Alemania conjunta sobre "lectura y escritura como una praxis cultural de la juventud". Este fue un estudio cualitativo empírico sobre la base de entrevistas "dialógicas" abiertos (Bajtín) que se centraron en esta praxis de los jóvenes. Además de Bajtín como un punto de vista metodológico, el concepto de una "ciencia

\footnotetext{
* Universität Siegen, Siegen, Alemanha.

${ }^{1}$ This project was jointly carried out by a Brazilian group under the direction of Maria Teresa Freitas (University of Juiz de Fora) and by a German group under my direction at the University of Siegen in 1998 and 1999.

${ }^{2}$ W. Benjamin (1928) presented a theoretical conception on this issue in his essay on the "Programm eines Proletarischen Kindertheaters" ("Plan for a Proletarian Children's Theater").
} 
romántica" de Luria se convirtió en fundamental para nuestro proyecto. Los objetivos de nuestra investigación fueron los siguientes: 1 . Comprender la lectura y escritura en su interrelación como una forma específica de la praxis culturales; 2 . Para contribuir por medio de la investigación sobre esta praxis específica a las dimensiones teóricas del concepto de "praxis cultural" como una praxis mediadas simbólicamente; 3. Para comprender mejor - precisamente por medio de esta praxis por parte de los niños y jóvenes - los cambios actuales en la lectura y la escritura. Con este fin, se procedió de la suposición de que los niños y jóvenes tienen una sensibilidad particular para simbolizar sus experiencias con respecto a los nuevos desarrollos en una sociedad; 4. Tenemos la intención de concretar estos objetivos en una "comparación cultural" de esta praxis por parte de los jóvenes brasileños y alemanes. Con las siguientes observaciones, no vamos a estar presentando el proyecto en su totalidad, sus resultados, o la discusión de los mismos. Más bien, nos gustaría hablar sobre un aspecto particular con más detalle: el problema de las diferencias culturales, la naturaleza explosiva de los cuales sólo se hizo evidente en el curso del proceso de investigación.

\section{Palabras clave}

Praxis culturales; la comparación cultural; diferencias culturales.

\section{AT FIRST GLANCE: UNEXPECTED COMMON FEATURES}

Where we speak about "youths" in what follows, we are referring to youths in Juiz de Fora, a Brazilian city in Minas Gerais with a population of approximately 400,000 and to youths in Siegen, a German city in NorthrhineWestphalia with a population of approximately 130.000 .

We had not anticipated the common features and the extent of these common features which became evident in the course of the "dialogical interviews".

Brazilian and German youths instrumentalize writing and reading for their own private problems and purposes. They utilize writing and reading, so to speak, to organize their own development. Thus, a conflict with formal schooling is inevitable. The school is a public place: reading and writing at school presents itself to the youths as a normative cultural asset - which is not at all or hardly related to their interests, needs, or experience.

Youths in Juiz de Fora and in Siegen who read and write are primarily readers and writers of themselves. Reading and writing offer particular possibilities to youths: In the course of this praxis, they realize themselves as the producers of their own development. Reading and writing provide an astonishing arsenal for making inner and outer surroundings "fit".

With regard to reading, this is expressed as private reading, oriented to one's own wants and needs: Almost everything is read without any critical distance or differentiation; the reading material is literally "devoured". All of the youths interviewed are acquainted with these intensive private forms of excessive reading. Yet, the female youths are more conscious of their own reading 
habits; they can also communicate more readily and more openly about them than can the boys. With writing, the situation is similar: it occurs intensively and eruptively as monological writing that tolerates no delay and is designed to construct an autonomous world of one's own.

However, the majority of the group of writers in both cultures are girls. This is also confirmed by quantitative research on reading. Male youths refer more frequently to new communications technologies such as the PC or the Internet, while the girls mention more traditional forms such as pencil and paper and transform these into specific forms of female culture. These female writers perceive themselves as writing on the basis of totally personal feelings, in an egoistic and self-centered manner, and, yet, they do this before a fictitious audience, before mysteriously present readers.

This dialectic of "public" and "private" presents itself differently with regard to reading. Reading is unambiguously considered to be an intimate phenomenon. Social exchange on what has been read is practically nonexistent. Yet, the communicative aspect of reading becomes visible at a different level. The unambiguously regressive manner of reading enables the reader to come into contact and to communicate with his or her own repressions, with that disjointed part of his or her own self and life-world. While writing is especially dominant among the girls, this form of reading can be observed among all of the youths.

\section{AT SECOND GLANCE: SPINOZA'S CATEGORIES AS PERSPECTIVES}

Within a second step of the joint project, the Brazilian research group read some of the German interviews and, conversely, the German group read some of the Brazilian ones. Without particular preconceptions and perhaps somewhat naively, we had a working understanding of culture in accordance with the paradigm of the cultural historical approach: "Culture as a medium constituted of historically cumulated artifacts which are organized to accomplish human growth" ${ }^{\prime 3}$.

Within the perspective of this general conception of culture, we

\footnotetext{
${ }^{3}$ As Sheldon $\mathrm{H}$. White pointed out in his foreword to M. Cole "Cultural Psychology" (1996): "In the formation of a human culture across historical time, cultural mediation produces a mode of developmental change in which the activities of prior generations are cumulated in the present as the specifically human part of the environment. The social world influences the individual not only through the agency of flesh and blood people, who converse, communicate, model or persuade, but through the social practices and objects unseen people have built up in the world around the individual. There are the prescribed forms of social interaction: routines, schemas, scripts, games, rituals, cultural forms. There are the manufactured objects that silently impregnate the future of the world with human intelligence: words, maps, television sets, subway stations" (XIV).
} 
discovered significant differences in the cultural praxis of reading and writing between Brazilian and German youths. A few examples follow:

All of the German youths, regardless of social stratum, demonstrated in comparison to the Brazilians:

- a more distinctive elaborateness in the use of language,

- a greater ability to reflect on oneself and on one's own process of reading and writing,

- a more reflective critique of public education etc. than among the Brazilian youths.

Whenever the German youths report on their personal and private reading habits, these accounts always include detailed descriptions of their "imaginative reading", whereas not a single Brazilian youth is concerned with the topic of his or her own "imaginative reading". By "imaginative reading" (ASSMANN, 1999), we mean the "miracle" of the transition from reading to seeing, the shift in media from text to picture: You are doing something, you are "compiling" letters, then, suddenly, something happens to you, and you find yourself within a picture.

Confronted with all of these differences, we in the German research group were quickly prepared to provide explanations involving the context of the particular culture and, above all, its history. That is, we put forth arguments along the lines of the significance of European literary culture, the high level of its public educational system and its long history in comparison to Brazil, a country that was a Portuguese colony for almost four hundred years, that abolished slavery only about a hundred years ago, that only for the last hundred years has had a public educational system which is, even today, in a catastrophic state, a country that is currently ranked eighth in the global economy and, yet, is characterized by the World Bank as the most unjust country in the world, a country in which there are unimaginable discrepancies between rich and poor.

To our surprise, our research project demonstrated that all of the analyzed differences had something to do with "more" or "less" - thus, with quantities ${ }^{4}$. The more carefully and exactly we attempted to analyze individual interviews from the perspective of the particular culture with the methods of discourse analysis, the more extensive and evident became the quantitative differences.

As a way of avoiding this aporia, Maria Benites suggested implementing as categories and, at the same time, as instruments of analysis, the general characterizations with which Spinoza describes and distinguishes human beings.

In his "Ethics" and his "TheologicalPolitical Treatise", Spinoza characterizes

\footnotetext{
${ }^{4}$ Yet, at the same time, our project was committed to Lurija's $(1983,190)$ conception of a "romantic science". The task was to reconstruct the individual case as a cosmos in which the universal appears in the concrete in a specific way.
} 
human beings as free and unfree. That person is free who is characterized by the emotions of pleasure: The reason for these emotions of pleasure is the correspondence between man and his capacity for activity. The emotions of pleasure release this capacity for activity; they develop and enhance it. The unfree are characterized by emotions of pain; these diminish the capacity for activity. In the third, fourth, and fifth books of his "Ethics", Spinoza "declines" an entire panorama of emotions emanating from pain: hatred, aversion, derision, contempt, envy, anger, guilt, compassion, piety, indignation, humiliation, shame, infuriation, revenge, loathing, etc. Spinoza even includes hope within this panorama and considers how this emotion renders humans unfree by promoting good behavior in the expectation of later, otherworldly rewards.

Those human beings characterized by passions of pain form a mutually dependent, self-perpetuating system consisting of three "types": the tyrant, the slave, and the priest. The tyrant requires sorrow in order to rule just as the slaves require the tyrant to whom they can submit and assign themselves. Both are held together by a hatred and resentment toward life. ${ }^{5}$ Priests

5 There is an intimate implicit connection between the slave and the tyrant which Spinoza illustrates with the concrete example of the monarchy in his "Theological-Political Treatise": "But if, in despotic statecraft, the supreme and demonstrate a sorrowful concern for the conditio humana in general and for human passions in particular. In doing so, they can both become extremely indignant and feign indifference, though never without a certain cynical smile.

With this categorization of human beings, Spinoza does not explicitly establish political, social, or historical concepts, but, rather, ethical ones. We become slaves when we are separated or alienated the furthest from our capacity for activity, when we are subject to the myths of superstition, to the delusions and mystifications of the tyrant or the priest. We are free when we are in accordance with our capacity for activity.

We understand Spinoza's ethics as a philosophy of "life" or, rather, as a philosophical theory of human activity. Using its central concept of capacity for activity, it investigates what it means to be a living human being.

What is the significance of implementing Spinoza's general ethical concepts as categories and as instruments of analysis? I would like to examine this question by briefly presenting an interview with a German youth and a

essential mystery be to hoodwink the subjects, and to mask the fear, which keeps them down, with the specious garb of religion, so that men may fight as bravely for slavery as for safety, and count it not shame but highest honour to risk their blood and their lives for the vainglory of a tyrant; yet in a free state no more mischievous expedient could be planned or attempted" (Foreword). 
further one with two Brazilian youths in an exemplary fashion.

Anna, a German youth, is 18 years old and lives with her parents. Her father is a low-level bank employee, her mother a housewife. Anna also has an older brother and, at the time of the interview, she was preparing for her Abitur (a German examination at the end of secondary school, in preparation for higher education).

In the course of the interview, Anna presents herself as a heroine who, at the cost of enormous sacrifices and struggle, manages to overcome the obstacles life has put in her way. She appears as a conqueror who sets off alone to discover some strange, unknown world. She departs from the boredom and comfort of her home and pays visits to libraries where she discovers new continents. She puts school and homework behind her so that she can become familiar with alternative forms of theater. She devotes much of her time to avant-garde cinema and writes screenplays. But, then again, we also learn - recounted in short asides - of her difficulties in establishing an emotional relationship to her family. She had never been read to as a child; no one in her family ever showed any interest in her reading. The situation is different when she is among her friends. She writes poems, reads them aloud to her best friend, and is asked to explain these poems. Anna feels happy in the role of the misunderstood writer - like Joyce or Kafka. In the course of the interview, she demonstrates an enormous vitality and energy for getting involved in extremely various activities. She criticizes school and the shortcomings of her literature classes and, somehow, she is opposed to society as a system. But she also plunges into a state of deep personal depression when her boyfriend breaks up with her for the first time. Like in a famous bolero phrase, her aim in life is to be truly happy.

The significance of our European culture is expressed in every detail of the interview. Anna feels compelled to read and write, to be involved in theater and film-making, in the final analysis, to search for a new language for opening the world to oneself. And yet she also senses that this world is somehow closed off.

The arrogance of the tyrant as a conqueror is present in Anna's language; she has the best weapons; she has energy and power; everything in her surroundings is at her disposal as a matter of course. - Yet something just doesn't seem to work - and Anna doesn't know what or why. In the course of the interview, the peculiar fragility of a youth who refuses to admit that she is fragile becomes evident. She doesn't want to be like all the others, but neither is she in a position to ask: Why are all the others the way they are? Nor does she wonder why she doesn't accept any of the usual female roles or why she admires no one or nothing in her surroundings as a model. Anna is alone - but, at the same time, she knows that many people are around her and are there for her. Anna 
suffers and, at the same time, enjoys her suffering.

Anna is the product of a culture of the tyrant who dominates language. Somehow, she senses this, and perhaps this is the reason why she looks for thousands of escape routes. However, in this shape of the tyrant, there also appears the slave who inevitably perpetuates and secures the culture of the tyrant. Perhaps this is the reason behind all of her insecurity and loneliness.

The second interview deals with Paula and Christiene, two Brazilian youths from Juiz de Fora who are 14 and 15 years of age. Paula lives with her stepfather, who is a bus-driver; her mother is a housewife. Paula does quite a bit of the housework; she does the cooking, brings her younger brothers and sisters home from school; she looks for work because somehow it is always hard to make ends meet in this household. Christiene's father works as a gatekeeper at the university. He lives separated from the family but in the same house, since they cannot afford two apartments. Christiene's mother works illegally; her older brothers and sisters also go to work. Paula is very orderly and an eager learner, although she hates her Portuguese teacher, whom she describes as being arrogant. She writes poems and hates politics: "I don't like the news, I don't want to hear about what is happening in Brazil." She has a boyfriend and she likes being in love very much.

Christiene likes to dance and to talk on the phone. She has very little money and often has to wait until her friends call her or she buys a phonecard so that her friends can call her at a phone booth.

At first reading, the entire interview provokes the impression of the banality of a dismal day-to-day life. The language level of both youths is "restricted", determined by discontinuities, as if at some meta-linguistic level they would constantly presume the understanding of the listener. By contrast, Anna explains everything with the utmost detail, as if her listener were essentially incapable of understanding her.

Anna begins many of her sentences with: “Ja, Ja, Ja!" - Paula's and Christiene's sentences almost always begin with: "no, no, no".

The films that Paula and Christiene go to see are far removed from their everyday life, which makes it impossible for them to stylize themselves as heroines. Paula and Christiene are only part of the audience. Anna, on the other hand, wants to be a director. Paula and Christiene dream of becoming fashion models and earning a great deal of money. Anna works on writing a screenplay. Paula and Christiene are content to record descriptions of their everyday life in an old calendar, but in a secret code. Anna is proud to present her poems. Paula and Christiene hide theirs bashfully.

For Anna, the future appears as something that one must conquer. For Paula and Christiene, the future means: working, earning little money, marrying and having children. 
At the end of the interview with Paula and Christiene, filled with consternation we asked ourselves: Who dominates these two? They have hardly any weapons with which they might fight against their own submissiveness. The figure of the slave is vibrantly present in all of their statements - and yet, real possibilities are available to them to escape and laugh at the figure of the tyrant. There are numerous levels at which they practice solidarity in their everyday life. There is joy, pleasure, carefree falling in love, etc. In the figure of the slave there also appears the profile of "free man". Paula and Christiene possess a certain authenticity with their knowledge of their own limitations and difficulties. This enables them to become persons who do not simply adapt to the dominant discourse, yet, at the same time, almost all of the usual clichés of the dominant culture industry and its illusions appear.

Now, in the cultural practices of these youths who takes the role of the priest? Teachers, the mass media, or the culture industry? Who are the priests of today, who, filled with a general sorrow in the form of total indifference and moral indignation, attempt to keep such youths from attaining real knowledge about themselves?

\section{INSTEAD OF A CONCLUSION - UNANSWERED QUESTIONS}

We have only been able to briefly suggest how and to what extent "slaves", "tyrants", "priests", and "free men" are present, vibrant, and in effect in the reading and writing of German and Brazilian youths, indeed, as dimensions of this cultural praxis. They never appear in the two interviews mentioned above in pure form, but, rather, always as superimpositions, much like palimpsests, as manuscripts which, after the deletion of the original text, are continually rewritten for the sake of economizing.

Now, Spinoza's categories are specific manifestations of affects which in their relationship to our capacity for activity constitute our personal existence as being free or unfree. They are philosophical-ethical concepts. In agreement with Spinoza, we consider them to be general and universal. But in what sense? Spinoza's concepts are categories. They exhibit the same relationship to reality as do works of art. A work of art relates itself in an absolute and precise manner to an ideal reality. For Spinoza's categories, this absolute and precise relationship is an ethical view of the world.

It is precisely this philosophical dimension which we find lacking in the comparative research and "crosscultural studies" we are familiar with; such studies remain confined to the level of a specific discipline and the methodology of a single field. In this 
predominantly methodical view, the reality to be explored already seems to have been grasped in its essence. What reading and writing as a cultural praxis of youths actually are, is basically already understood. In that case, recognition and comprehension is a methodically safeguarded, increasingly precise, stepby-step approximation to reality. The differences which become evident in the course of comparative studies are then discussed as the aporia of an abstract universalism or of an equally abstract cultural relativism.

We would like to suggest implementing Spinoza's categories as explanatory principles. In my view, the function and effect of explanatory principles is to provide access to a concrete sphere of reality, in this case, to the cultural praxis of reading and writing. If, however, these principles are to explain something, that is, if they are to be consciously utilized as instruments, then these categories are not simply and naively to be equated with a tool. Their methodological potential is not, as with a tool, to be found within the category itself, but, on the contrary, arises from its context, or, more precisely, its interconnection with the fundamental philosophical problem of Spinoza's ethics, with the ethical view of the world, which was not able to be expounded and discussed here.

For comparative cultural studies, Spinoza's ethical categories constitute a general philosophical meta-level which allows for the empirical study and comparison of two different cultures, or, more precisely, of specific cultural practices of youths in different cultures without becoming entangled in the dilemma of "more" and "less". With reference to comparative cultural studies, Spinoza's categories provoke the following questions:

1. In what way and to what extent does the particular culture function as a medium that produces "free men" or "slaves", "tyrants", and "priests" within the cultural practices?

2. By means of which mechanisms do such processes function within the particular culture to be studied?

In the last year of his life, Vygotsky studied Spinoza and the problem of affects and emotions intensively. In connection with his reflections on a theory of inner speech, he writes: "Thought [...] is not the last instance in this entire process. It arises not from some other thought, but, rather, from a motivating sphere of consciousness which encompasses our drives and needs, our interests and impulses, our affects and emotions. Behind thought are affective and volitional tendencies. [...] We can only then completely understand someone else's thought if we discover its affective-volitional background" (354).

(Translated from German by Thomas La Presti) 


\section{REFERENCES}

ASSMANN, A. Lesen als beleben: zum verhältnis von medium und imagination. Vortrag: [s.n.], 1999. Available in: <www.ph.uni-heidelberg.de/org/lz/assm.htm>.

BENJAMIN, W. Programm eines proletarischen Kindertheaters 1928. In: .über kinder, jugend und erziehung. Frankfurt: Suhrkamp, 1969. p. 79-86.

COLE, M. Cultural Psychology. A once and future discipline. Cambridge: Havard University Press, 1996.

CURLEY, Edwin (Editor and translator). The collected works of Spinoza. Princeton: University Press, 1985. v. 1.

LURIJA, A. R. Verso un analisi della personalità concreta. La "scienza romantica": ritratti non imaginari. In: . Uno sguardo sul passato. Considerazioni retrospettive sulla vita di uno psicologo sovietico. Presentazione di M.S. Vegetti. Firenze: Giunti Barbèra, 1983.

SPINOZA, Benedictus de. A Theologico-Political Treatise [Part I]. Translated by R. H. M. Elwes July, 1997 [Project gutenberg etext 989]. [S.I.: s.n.], 1670.

. Ethik in geometrischer Ordnung dargestellt. Neu übersetzt, herausgegeben , mit einer Einleitung versehen von W. Bartuschat (1999). Lateinisch-Deutsch. Hamburg: Meiner, 1677.

VYGOTSKY, L. S. Denken und Sprechen (1964). Berlin: Akademie Verlag, 1934.

\section{Sobre o autor:}

Bernd Fichtner: Universität Siegen, Siegen, Alemanha.

E-mail: fichtner@paedagogik.uni-siegen.de

\section{Recebido em fevereiro de 2016.}

Aprovado para publicação em março de 2016. 